\title{
Akar Sejarah Moderasi Islam Pada Nahdlatul Ulama
}

\author{
A. Jauhar Fuad \\ Institut Agama Islam Tribakti Kediri \\ info.ajauharfuad@gmail.com
}

This paper explains the history of Islamic moderation in the Nahdlatul Ulama organization. This paper is part of the results of library research by collecting several research books and research journals that are written on the theme of writing. NU as the largest Islamic organization in Indonesia has a strong commitment in carrying out moderate Islam. NU was born in response to the development of external politics. International developments have led to the formation of NU, while the socio-religious and political situation of the country is only part of the reason for establishing this organization. One of the most important factors leading to the formation of $\mathrm{NU}$ is the problem of representation in protecting the interests of traditionalist Muslims who feel threatened by the rise of the well-known Wahhabi movement which has ruled the Arabian Peninsula. In the following developments by strengthening the flow of globalization, especially cultural globalization, both in the form of urbanization and westernization, Islamic moderation is also needed as the main stream in protecting Islam. So NU carries the concept of Islamic Nusantara to stem the flow of globalization that leads to radical and liberal understandings.

\section{Keywords: Historical Roots, Islamic Moderation, Nahdlatul Ulama}

\begin{abstract}
Abstrak
Tulisan ini menjelaskan tentang sejarah moderasi Islam dalam organisasi Nahdlatul Ulama. Tulisan ini bagian dari hasil penelitian kepustakaan dengan mengumpulkan beberapa buku hasil penelitian dan jurnal hasil penelitian yang berkanan dengan tema tulisan. NU sebagai organisasi Islam terbesar di Indonesia memiliki komitmen yang kuat dalam mengusung Islam moderat. NU lahir atas respons terhadap perkembangan politik eksternal. Perkembangan internasional telah mengarah pada pembentukan NU, sementara keadaan sosial-keagamaan dan politik negara ini hanya bagian dari alasan untuk mendirikan organisasi ini. Salah satu faktor terpenting yang mengarah pada pembentukan NU adalah masalah representasi dalam melindungi kepentingan muslim tradisionalis yang merasa terancam oleh kebangkitan gerakan Wahhabi yang dikenal radikal yang telah menguasan kawasan Jazirah Arab. Pada perkembangann berikut dengan penguatan arus globalisasi, terutama globalisasi budaya, baik dalam bentuk urbanisasi dan westernisasi, diperlukan pula moderasi Islam sebagai arusutama dalam menjaga Islam. maka NU mengusung konsep Islam Nusantara untuk membendung arus globalisasi.
\end{abstract}

Kata Kunci: Akar Sejarah, Moderasi Islam, Nahdlatul Ulama 


\section{Pendahuluan}

Penulis melihat bahwa isu radikalisme menjadi isu yang sangat krusial. Terlebih di Indonesia sebagai negara Islam terbesar di dunia dan Negara demokrasi terbesar ke tiga di dunia, memiliki peran penting dalam perpolitikan global. Persoalan radikalisme menjadi perhatian pemerintah, akademisi, masyarakat pada umumnya. Hal ini terjadi karena radikalisme berujung pada sikap intoleransi dan berakhir pada aksi teror yang terjadi di Indonesia akan menjadi perhatian dunia.

Kelompok radikal seringkali menyisir dengan menyuarakan pemurnian ajaran Islam, penolakan terhadap sistem demokrasi, dan berujung pada aksi terror. ${ }^{1}$ Tiga hal tersebut akhir-akhir ini muncul kembali sebagai isu yang membuat banyak pihak prihatin dan terusik atas berbagai statemen dan peristiwa tersebut. Pertama, isu tentang pemurnian ajaran Islam menyisir penggunaan nama. Ceramah ustad Basalamah meresahkan banyak orang atau keluarga dengan kepemilikan nama seperti: Wisnu, Sri, dan Dewi. Ia mengatakan “...Ada satu bahasa yang sering diungkapkan oleh beberapa manusia, beberapa istilah, yang sebenarnya tidak boleh, yaitu dewi pertiwi atau bumi pertiwi. Pertiwi itu dewi penguasa Bumi. Kalau bicara bumi pertiwi, berarti kita meyakini ada Tuhan selain Allah."2 Kedua, pengibaran bendera Hisbu Tahrir Indonesia (HTI) pada pelantikan Rohis SMKN 2 Seragen $^{3}$. HTI adalah organisasi terlarang di Indonesia. Ia getol mengkampanyekan pergantian sistem demokrasi dengan sistem khilafah. ${ }^{4}$ Ketiga, kasus penusukan Menkopolhukam Wiranto dengan pisau kunai membawa dampak besar

\footnotetext{
${ }^{1}$ A. Jauhar Fuad, Penetrasi Neo-Salafisme Dalam Lembar Kerja Siswa Di Madrasah (Jakarta: Kementerian Agama RI, 2015); A. Jauhar Fuad, "Infiltrasi Salafi Wahabi pada Buku Teks di Madrasah dan Respons Warga Nahdliyin,” Marâji: Jurnal Ilmu Keislaman 1, no. 2 (March 2, 2015): 361-92.

${ }^{2}$ Prima Sulistya, "Ribetnya Jadi Orang Islam yang Dinamai Pakai Nama Sanskerta Menyerupai Dewa-Dewi Hindu - Mojok.co," Mojok (blog), October 7, 2019, https://mojok.co/prm/ulasan/pojokan/ribetnya-jadi-orang-islam-yang-dinamai-pakai-nama-sanskertamenyerupai-dewa-dewi-hindu/.

${ }^{3}$ Liputan6.com, “Ada Bendera HTI di SMKN 2 Sragen, GP Ansor: Pelajar Harusnya Steril dari Radikalisme,” liputan6.com, October 17, 2019, https://www.liputan6.com/regional/read/4088206/adabendera-hti-di-smkn-2-sragen-gp-ansor-pelajar-harusnya-steril-dari-radikalisme.

${ }^{4}$ Abdul Chalik, "Terjebak Antara Demokrasi Dan Kedaulatan Negara: Anomali Pembubaran Hizbut Tahrir Indonesia Dan Bayang- Bayang Neo-Otoritarianisme" (Proceeding of the International Conference on Muslim Society and Thought, Surabaya - Indonesia, 2017), 51-68, http://digilib.uinsby.ac.id/id/eprint/23566; Abd Qohar and Kiki Muhamad Hakiki, "Eksistensi Gerakan Idiologi Transnasional HTI Sebelum dan Pasca Pembubaran," KALAM 11, no. 2 (December 31, 2017): 365-96, https://doi.org/10.24042/klm.v11i2.1403; Syamlan Syamlan, "Kebijakan Pemerintah Indonesia Terhadap Pembubaran Organisasi Hizbut Tahrir Indonesia (HTI)" (Thesis, MIHI UMY, 2018), http://repository.umy.ac.id/handle/123456789/21498. 
pada situasi keamanan Negara. Kejadian tersebut, menunjukkan rentannya pengamanan di Indonesia dan menjadi sorotan banyak pihak termasuk pihak internasional. ${ }^{5}$

Radikalisasi akan terus terjadi, jika tidak diantisipasi dengan baik. Radikalisme sekarang tidak hanya sekedar melekat pada para mantan teroris, tetapi sudah masuk pada masyarakat secara luas. Kelompok radikal dapat masuk pada intitusi Kepolisian. ${ }^{6}$ Penyebaran paham radikal tidak melulu menyasar masyarakat biasa, pegawai lembaga negara, kementerian, bahkan aparat keamanan pun tidak luput dari pengaruh paham radikal. ${ }^{7}$ Bahkan Ryamizard menuturkan ada sekitar 3\% anggota TNI yang sudah terpapar paham radikal. Sebanyak $23,4 \%$ mahasiswa universitas dan ada $23,3 \%$ pelajar SMA setuju dengan negara Islam/khilafah; ada $18,1 \%$ pegawai swasta menyatakan tidak setuju dengan ideologi Pancasila; ada 19,4\% PNS menyatakan tidak setuju dengan ideologi Pancasila; dan 19,1\% pegawai BUMN tidak setuju dengan Pancasila. ${ }^{8}$

Ideologi pancasila sedang terancam. Ideologi adalah sistem ide dan berbagai representasi yang mendominasi pikiran manusia atau kelompok sosial. ${ }^{9}$ Ideologi dimaksudkan sebagai artikulasi nyata dan asosiasi kepentingan sehingga tidak ada kelompok yang berlawanan atau menyebabkan kelompok yang bertentangan muncul. ${ }^{10}$ Maka disini perlu ada penguatan dalam hal ideologi.

Pendidikan memiliki peran dalam melakukan trasformasi ideologi bangsa dan ideologi keagamaan. Ideologi sebuah lembaga pendidikan menjadi penting dalam menentukan arah tujuan pendidikan. Setidaknya pendidikan ditentukan oleh kebijakan pendidikan, tujuan pendidikan dan kurikulum. Ketiga aspek ini sangat mempengaruhi bentuk dan format sebuah lembaga pendidikan. Ideologi adalah sistem ide dan berbagai representasi yang mendominasi pikiran manusia atau kelompok sosial. ${ }^{11}$ Pemilihan terhadap ideologi yang salah dapat berdampak panjang bagi kelangsungan kehidupan

\footnotetext{
${ }^{5}$ Jobpie Sugiharto, “Penusukan Wiranto, Pengamat: Jadi Sorotan Internasional," Tempo, October 11, 2019, https://nasional.tempo.co/read/1258498/penusukan-wiranto-pengamat-jadi-sorotaninternasional.

${ }^{6}$ Tim detikcom, "Polwan Terpapar Radikalisme Dipecat Dari Institusi Polri," detiknews, 2019, https://news.detik.com/berita/d-4743324/polwan-terpapar-radikalisme-dipecat-dari-institusi-polri.

${ }^{7}$ Nashih Nashrullah, "BNPT: TNI Dan Polri Bisa Terpapar Radikalisme Terorisme," Republika Online, September 24, 2019, https://republika.co.id/share/pybqpt320.

${ }^{8}$ Ryamizard Ryacudu, "Menhan Sebut 3 Persen Anggota TNI Terpapar Radikalisme," nasional, 2019, https://www.cnnindonesia.com/nasional/20190619113157-20-404549/menhan-sebut-3-persenanggota-tni-terpapar-radikalisme.

${ }^{9}$ Louis Althusser, Tentang Ideologi: Marxisme Strukturalis, Psikoanalisis, Cultural Studies (Yogyakarta: Jalasutra, 2008).

${ }^{10}$ Ralf Dahrendorf, Konflik Dan Konflik Dalam Kelas Masyarakat Industri; Sebuah Analisa Kritik (Jakarta: Rajawali, 1986).

${ }^{11}$ Althusser, Tentang Ideologi: Marxisme Strukturalis, Psikoanalisis, Cultural Studies.
}

Tribakti: Jurnal Pemikiran Keislaman

Volume 31, Nomor 1, Januari 2020 
berbangsa, bernegara dan beragama. Maka Islam sebagai agama mesti hadir dalam menawarkan ideologi keagamaan yang moderat.

Di sinilah, perlu hadir moderasi beragama dalam mengatasi persoalan radikalisme. Untuk itu moderasi Islam pentuk diposisikan menjadi arus utama pendidikan Islam di Indonesia. ${ }^{12}$ Arus utama ini perlu dikembangkan menjadi model pendidikan moderasi Islam dunia. "Kementerian Agama menjadikan moderasi Islam dan pembelajaran Islam rahmatan lil Alamin sebagai arus utama pendidikan Islam, baik di tingkat dasar, menengah, hingga perguruan tinggi ". ${ }^{13}$ Prinsip moderasi yang merupakan perspektif dan ideologi adalah alat pemersatu dalam keberagaman, sehingga keberadaannya mutlak di negara multikultural. ${ }^{14}$

Islam di Indonesia masih dianggap sebagai Islam moderat. Nahdlatul Ulama dapat dilihat sebagai penjaga moderatisme Islam di Indonesia ${ }^{15}$. Nahdlatul Ulama sejauh ini dalam landscape Islam Indonesia, dapat berfungsi sebagai batu loncatan untuk membangun formulasi Islam Indonesia yang lebih bertanggung jawab di masa depan ${ }^{16}$.

Tulisan ini untuk menghadirkan tentang akar sejarah moderasi yang ada pada tubuh Nahdlatul Ulama. Setidaknya menjelaskan latar belakang kelahiran NU dan sikarnya dalam perekembangan kekinian ketika berhadapan dengan kelompok radikal.

\section{Metode Penelitian}

Tulisan ini hasil dari penelitian kualitatif dengan menggunakan jenis penelitian keputakaan. Sumber data yang digunakan dalam penelitian ini adalah beberapa buku hasil penelitian, dan jurnal ilmiah. Misalnya buku hasil penelitian: (1) Abdul Muchith Muzadi. NU Dalam Perspektif Sejarah Dan Ajaran: Refleksi 65 Th. Ikut NU. Surabaya: Khalista, 2006; (2) Greg Fealy, Ijtihad Politik Ulama; Sejarah NU 1952-1967. Lkis Pelangi Aksara, 2012; dan (3) Martin van Bruinessen, NU: Tradisi, Relasi-Relasi Kuasa, Pencarian Wacana Baru. Yogyakarta: Lkis Pelangi Aksara, 1994 dan lainnya. Beberapa jurnal ilmiah: (1) Khabibi Muhammad Luthfi, "Islam Nusantara: Relasi Islam Dan Budaya Lokal." Shahih: Journal of Islamicate Multidisciplinary 1, no. 1 (June 28, 2016); (2) Masdar Hilmy, "Whither Indonesia's Islamic Moderatism? A Reexamination on the Moderate Vision of Muhammadiyah and NU." Journal of Indonesian Islam 7, no. 1 (June 1, 2013); (3) Robin Bush, and Greg Fealy. "The Political Decline of Traditional Ulama in Indonesia." Asian Journal of Social Science 42 (January 1, 2014); (4) Saiful Mustofa,

\footnotetext{
${ }^{12}$ A. Jauhar Fuad and Suko Susilo, "Mainstreaming Of Islamic Moderation In Higher Education: The Radical Experience Conter," Proceedings of Annual Conference for Muslim Scholars 3, no. 1 (November 26, 2019), http://proceedings.kopertais4.or.id/index.php/ancoms/article/view/261.

13 Ishom Yusqi, "Kemenag Jadikan Moderasi Islam Sebagai Arus Utama Pendidikan Islam," Kementrian Agama Republik Indoneisa, $\quad$ March $18, \quad 2017$, https://www2.kemenag.go.id/berita/472922/kemenag-jadikan-moderasi-islam-sebagai-arus-utamapendidikan-islam.

14 Jasminto Jasminto, "Urgensi Teori Andragogi Dalam Memperkuat Visi Moderat Islam Di Indonesia," in Proceedings: Annual Conference for Muslim Scholars, 2018, 643-51, http://proceedings.kopertais4.or.id/index.php/ancoms/article/view/166.

${ }^{15}$ Zakiya Darajat, "Muhammadiyah Dan NU: Penjaga Moderatisme Islam Di Indonesia," Hayula: Indonesian Journal of Multidisciplinary Islamic Studies 1, no. 1 (January 30, 2017): 79, https://doi.org/10.21009/hayula.001.1.05.

${ }^{16}$ Masdar Hilmy, "Whither Indonesia's Islamic Moderatism? A Reexamination on the Moderate Vision of Muhammadiyah and NU," Journal of Indonesian Islam 7, no. 1 (June 1, 2013): 24, https://doi.org/10.15642/JIIS.2013.7.1.24-48. 
"Meneguhkan Islam Nusantara Untuk Islam Berkemajuan: Melacak Akar Epistemologis Dan Historis Islam (Di) Nusantara." Epistemé: Jurnal Pengembangan Ilmu Keislaman 10, no. 2 (December 6, 2015); (5) Taufik Bilfagih. "Islam Nusantara; Strategi Kebudayaan Nu Di Tengah Tantangan Global." Aqlam: Journal of Islam and Plurality 1, no. 2 (January 31, 2018); dan (6) Zakiya Darajat. "Muhammadiyah Dan NU: Penjaga Moderatisme Islam Di Indonesia." Hayula: Indonesian Journal of Multidisciplinary Islamic Studies 1, no. 1 (January 30, 2017).

Riset ini, lebih mengedapankan penggunaan dokumen, dan sumber cetak lainnya, sebagai sumber utama dalam penulisan. Maka teknik pengumpulan data menggunakan dokumentasi. Analisis data menggunakan konten analisis dengan melihat isi/konten dari sumber bacaan yang menjadi subjek kajian. Peneliti berusaha menguraikan secara objektif, sistematik dan kuantitatif dari setiap sumber data yang diperoleh.

\section{Temuan dan Pembahasan}

\section{Latar Lahirnya Nahdlatul Ulama}

Sebelum membahas lebih jauh mengenai latar lahirnya Nahdlatul Ulama, perlu penulis kemukakan terlebih dahulu bahwa Nahdlatul Ulama merupakan pengusung Islam tradisional di Indonesia. Istilah tradisionalis memiliki dua makna; satu bersifat merendahkan sementara yang lain netral. Pertama, istilah tradisionalis berarti merendahkan jika digunakan dengan merujuk pada model kuno muslim dari desa tradisional dalam agama, intelektual konservatif, oportunistik politik dan budaya sinkretik ${ }^{17}$. Kedua, pemahaman yang lebih umum tentang muslim tradisional menunjukkan bahwa mereka adalah sekelompok orang yang percaya bahwa muslim yang tidak memiliki keahlian yang cukup untuk melakukan ijtihad harus mengambil salah satu dari empat mazhab hukum dan mengadopsi pendekatan yang bertahap dan toleran untuk berdakwah ketika berurusan dengan lokal tradisi. Fakta bahwa praktik Islam kadangkadang tampaknya dicampur dengan tradisi lokal tidak berarti bahwa mereka menganggap tradisi lokal sebagai tradisi Islam; alih-alih itu hanya masalah pendekatan. ${ }^{18}$.

Keunikan kelahiran NU terletak pada waktu dan karakter kemunculannya. Dalam hal waktu, pendirian NU tidak bisa dilihat hanya dari apa yang terjadi selama pendiriannya. NU telah ada selama lebih dari 93 tahun, tetapi masih mempertahankan karakter awalnya, meskipun maraknya perubahan sosial-politik di Negara ini. Selama 25

${ }^{17}$ Clifford Geertz, The Religion of Java (London: University of Chicago Press, 1976).

${ }^{18}$ Zamakhsyari Dhofier, The Pesantren Tradition: The Role of the Kyai in the Maintenance of Traditional Islam in Java (Arizona: Monograph Series Press, Program for Southeast Asian Studies, Arizona State University, 1999). 
tahun, NU berada di bawah kekuasaan penjajah Belanda dan Jepang, 20 tahun di bawah pemerintahan Soekarno, lebih dari 32 tahun di bawah rezim Soeharto, dan sekarang di bawah proses demokratisasi Indonesia yang sedang berlangsung ${ }^{19}$.

NU didirikan setelah sejumlah organisasi keagamaan dan organisasi Nasional berkembang dengan motif masing-masing. Organisasi-organisasi ini didirikan ketika Indonesia berada di bawah kekuasaan kolonial Belanda. Selama masa ini, gerakan muslim berperang melawan penjajah yang juga membawa Agama Kristen dan menentang praktik dan interpretasi Islam di antara mereka. ${ }^{20}$ Gerakan muslim dimaksud adalah gerakan yang didorong dan diikuti oleh orang-orang yang beragama Islam meskipun minat mereka berbeda satu sama lain.

Kepentingan yang diangkat oleh organisasi-organisasi ini lebih fokus pada masalah ekonomi, agama dan etnis. Contoh yang bagus dari organisasi komunitas (kelompok berbasis etnis) adalah Jam'iyyat Khair. Meskipun Jam'iyyat Khair terbuka untuk setiap Muslim, pendiri dan pemimpin dan mayoritas pengikutnya khususnya adalah orang Arab kaya yang menganggap muslim Arab secara agama "lebih unggul” dari pada muslim nonArab. Mereka mengatakan nahnu hadramiyyun 'ala kulli syai (kami adalah Hadrami di atas segalanya), sebagaimana dinyatakan oleh Al-Bashir ${ }^{21}$

Inisiatif kiai untuk membentuk NU sebenarnya lebih merupakan respons terhadap perkembangan politik eksternal. Dalam ajaran lain, perkembangan internasional telah mengarah pada pembentukan $\mathrm{NU}^{22}$ sementara keadaan sosial-keagamaan dan politik Negara ini hanya bagian dari alasan untuk mendirikan organisasi ini. Salah satu faktor terpenting yang mengarah pada pembentukan NU adalah masalah representasi dalam melindungi kepentingan Muslim tradisionalis yang merasa terancam oleh kebangkitan gerakan Wahhabi dan keinginan mereka untuk berpartisipasi dalam memecahkan masalah yang terus-menerus dihadapi oleh umat Islam. Ancaman Wahhabisme di Makah dan sekitarnya untuk menghancurkan banyak tradisi adalah alasan langsung untuk pembentukan NU. Bagi Muslim tradisional, ada kebutuhan mendesak untuk membentuk persatuan dan kekuatan di antara mereka.

\footnotetext{
${ }^{19}$ Asyari, Nalar Politik NU-Muhammadiyah ; Overcrossing Java Sentris.

${ }^{20}$ George McTurnan Kahin, Nationalism and Revolution in Indonesia (SEAP Publications, 2003); Harry J. Benda, "Indonesian Islam Under the Japanese Occupation, 1942-45," Pacific Affairs 28, no. 4 (1955): 350-62, https://doi.org/10.2307/3035318.

${ }^{21}$ Natalie Mobini-Kesheh, The Hadrami Awakening: Community and Identity in the Netherlands East Indies, 1900-1942 (Cornell: SEAP Publications, 1999).

${ }^{22}$ Bruinessen, NU: Tradisi, Relasi-Relasi Kuasa, Pencarian Wacana Baru. 
Istilah nahdhah pertama kali digunakan dalam konteks studi NU ketika Wahab Chasbullah dan Mas Mansour mendirikan madrasah bernama Nahdlatul Wathan (Kebangkitan Nasional) pada tahun 1916 (Madrasah ini nantinya akan dimasukkan ke dalam Muhammadiyah). Pada tahun 1918, Wahab Chasbullah menjadi salah satu pedagang muslim yang mendirikan Nahdlatul Tujjar (Kebangkitan Pedagang). Dalam asosiasi ini ia memegang posisi bendahara. Asosiasi ini digunakan untuk menghubungkan jaringan perdagangan di berbagai masyarakat Islam tradisionalis.

Pada tahun yang sama (1918), bersama dengan KH. Akhmad Dachlan dari Kebondalem (untuk membedakannya dari pendiri Muhammadiyah), ia mendirikan kelompok diskusi muslim bernama Taswirul Afkar, yang secara longgar berarti 'konstelasi pemikiran'23. Kelompok diskusi ini mengadakan debat reguler tentang masalah agama, seperti masalah ijtihad dan taqlid (mengikuti interpretasi hukum ulama). Kegiatan Taswirul Afkar memiliki kemiripan dengan Jiurnal des Dbats, ${ }^{24}$ sebuah jurnal yang diterbitkan di Paris di mana ada perdebatan antara al-Afghani dan Ernest Renan tentang masalah hubungan Islam dan sains. Jurnal ini tidak hanya dapat diakses di Timur Tengah, tetapi juga telah diterjemahkan ke dalam bahasa Arab.

Perkembangan dunia Islam ditandai oleh dua peristiwa penting, yaitu: pertama, Khalifah Abdul Majid digulingkan dari posisinya oleh Mustafa Kamal (pemimpin nasionalis Turki). Turki menyerahkan urusan khilafah kepada umat Islam di seluruh dunia. Menanggapi perkembangan Kairo di bawah kepemimpinan Syaikh al Azhar akan mengadakan pertemuan internasional untuk membahas khilafah. Kedua, penaklukan Mekah oleh Abdul Aziz bin Su'ud yang didukung oleh Wahhabi dari kekuatan Syarif Husain. Steenbink menyebut perang di Semenanjung Arab sebagai "perang Wahabi” ${ }^{25}$.

Kemenangan Ibnu Su'ud membuat masalah Wahabi menguat lagi setelah dilemahkan oleh hasil keputusan kongres Surabaya yang memposisikan Muhammadiyah dan al-Irsyad bukan Wahhabi. Reputasi Wahabi, yang dikenal radikal, dogmatis, dan tidak mengenal kompromi, membuat kaum tradisionalis khawatir bahwa kemenangan mereka akan diikuti dengan pemberantasan tradisi agama dari tanah Hijaz, meskipun Hijaz bukan hanya tujuan ibadah tetapi juga ilmiah. Kekhawatiran itu menjadi kenyataan, pemerintah Arab Saudi saat itu mulai menghancurkan peninggalan sejarah Islam,

\footnotetext{
${ }^{23}$ Greg Fealy, Ijtihad Politik Ulama ; Sejarah NU 1952-1967 (Lkis Pelangi Aksara, 2012).

${ }^{24}$ Nikki R. Keddie and Jamāl al-Dīn Afghān̄̄, An Islamic Response to Imperialism: Political and Religious Writings of Sayyid Jamal Ad-Din "al-Afghani”" (University of California Press, 1983).

${ }^{25} \mathrm{Karel}$ A. Steenbrink, Dutch Colonialism and Indonesian Islam: Contacts and Conflicts, 1596-1950 (Amsterdam-New York: Rodopi, 2006).
}

Tribakti: Jurnal Pemikiran Keislaman

Volume 31, Nomor 1, Januari 2020 
melarang tradisi agama dan selalu menghalangi madzhab selain madzhab Wahabi, terutama empat madzhab. Untuk mendapatkan pengakuan dari komunitas internasional sebagai satu-satunya penerus dunia Islam, mereka mengundang negara-negara Muslim atau jemaat dari seluruh dunia (termasuk Indonesia) untuk menghadiri konferensi Khilafah di Arab Saudi, meskipun akhirnya gagal. ${ }^{26}$

Ulama Indonesia sangat menolak tindakan penguasa Arab Saudi. Ulama pesantren yang terlibat dalam delegasi ulama Islam Indonesia yang akan menghadiri konferensi khilafah untuk mencari pengalaman untuk menyampaikan pesan dari mereka yang mewakili Indonesia ke Negara baru Arab Saudi. Namun, ini terhambat oleh penolakan berbagai kelompok Islam lainnya dengan alasan bahwa pesantren tidak memiliki organisasi seperti Muhammadiyah, Syarikat Islam, dan lainnya. ${ }^{27}$ Kemudian para ulama membentuk asosiasi yang disebut Syubbanul Wathan, untuk membahas isu-isu hukum agama, program dakwah, peningkatan pengetahuan dan lain-lain. ${ }^{28}$

Forum kongres Islam ke-4 di Yogyakarta memutuskan bahwa delegasi kongres Makkah adalah HOS Cokroaminoto dari SI (Syarekat Islam) dan Mas Manshur dari Muhammadiyah. Sementara itu kandidat yang terpisah dari Islam tradisionalis K.H Abdul Wahab Hasbullah dijatuhkan dari delegasi ke Mekkah. Latar belakang penolakan ini telah memicu antusiasme para pesantren untuk menunjukkan kemandirian dan kekuatan mereka. Tekad untuk mengirim sendiri delegasi pesantren dengan nama Komite Hijaz yang digunakan untuk menghadapi Arab Saudi. Pembentukan acara Hijaz di desa Kertopaten Surabaya pada tanggal 31 Januari 1926 dan hadir di Majelis termasuk Hadratus Syaikh Hasyim Asy'ari, KH Abdul Wahab Hasbullah, KH Bishri Syansuri, K. Raden Asnawi, KH Ma'shum, KH Nawawi, KH Ridlwan, KH Faqih dan KH Abdul Halim. ${ }^{29}$

Ketua Komite Hijaz yang dipimpin oleh Hasan Gipo dibantu oleh mbah Shodiq, dan sebagai juru bicara adalah K.H Abdul Wahab Hasbullah, Sheikh Ghanaim al Mishri dan Kyai Dahlan (Kertosono) yang saat ini belajar di Hijaz sebagai pendamping. Tuntutan yang diajukan oleh panitia Hijaz adalah: (1) kebebasan bermadzhab; (2) penjelasan tentang hukum yang berlaku di Hijaz; (3) tarif Haji; (4) mempertahankan tempat-tempat

\footnotetext{
${ }^{26}$ Abdul Muchith Muzadi, NU Dalam Perspektif Sejarah Dan Ajaran: Refleksi 65 Th. Ikut NU (Surabaya: Khalista, 2006), 33.

${ }^{27}$ Muzadi, 34.

${ }^{28}$ Andree Feilliard, NU Vis-a-Vis- Negara (Yogyakarta: LKiS, 1999), 10.

${ }^{29}$ Fealy, Ijtihad Politik Ulama ; Sejarah NU 1952-1967; Greg Fealy and Robin Bush, "The Political Decline of Traditional Ulama in Indonesia The State, Umma and Nahdlatul Ulama," Asian Journal of Social Science 42, no. 5 (2014): 536. 
bersejarah, termasuk makam Nabi dan Sahabat Nabi; dan (5) menjawab surat yang diajukan dua utusan..$^{30}$

Raja Sa'ud menanggapi permohonan itu, terutama dengan kebebasan bermadzhab. Juga tidak ada yang disebutkan dalam surat balasan Raja Sa'ud. Pada saat perkembangannya, kebebasan untuk mengajar dan mempraktikkan berbagai madzhab di Masjid al-Haram dan masjid Nabawi tidak memiliki kompilasi keseragaman di Haramain. Ulama yang mengajar dan mempraktikkan aliran pemikiran Syafi'i karena hanya bisa dilakukan di rumah. ${ }^{31}$ Komite Hijaz ini pada akhirnya oleh K.H. Hasyim Asy'ari diganti namanya menjadi Nahdlatul Oelama (NO). ${ }^{32}$

Kedekatan ulama satu sama lain membantu mempercepat proses rekonsiliasi umat Islam di nusantara. Ulama Islam membentuk organisasi sebagai wadah untuk mempertahankan dan mengembangkan ajaran Islamahlussunnah wal jama'ah, dan mewujudkan cita-cita "izzul al Islam wa al muslimin". Dengan demikian NU dan pesantren memiliki hubungan yang sangat erat. Hubungan antara keduanya seperti hubungan anak dengan orang tua. Karena NU lahir dari rahim pesantren. NU lahir dari ulama pesantren di Jawa yang memiliki hubungan emosional yang sangat kuat di antara mereka ${ }^{33}$.

Kebanyakan ulama memiliki hubungan yang melebihi ruang lingkup tempat tinggal mereka. Melalui hubungan perkawinan dan kekeluargaan, jaringan transmisi pengetahuan dan keramahan, atau melalui organisasi, para ulama memperkuat keberadaan pesantren mereka. Kesamaan ini menghasilkan homogenitas kehidupan, budaya dan praktik keagamaan di lingkungan pesantren, sehingga pantas disebut subkultur, yaitu subkultur pesantren di tengah masyarakat Indonesia. ${ }^{34}$ Subkultur ini terinspirasi oleh Aswaja Islam. Sub budaya inilah yang menjadi modal dan dasar utama pembentukan NU.

Pada konferensi NU 1928 Anggaran Dasar/AD dirumuskan, dalam tujuan organisasi itu dinyatakan untuk memegang teguh pada salah satu dari empat Imam Madzhab, Imam Muhammad bin Idris al-Syaf'i, Imam Malik bin Anas, Imam Abu Hanifah dan Imam Ahmad bin Hanbal. ${ }^{35}$ Berdasarkan paparan di atas, dapat ditarik

\footnotetext{
${ }^{30}$ Muzadi, NU Dalam Perspektif Sejarah Dan Ajaran: Refleksi 65 Th. Ikut NU; Robin Bush and Greg Fealy, "The Political Decline of Traditional Ulama in Indonesia," Asian Journal of Social Science 42 (January 1, 2014): 536, https://doi.org/10.1163/15685314-04205004.

${ }^{31}$ Bush and Fealy, "The Political Decline of Traditional Ulama in Indonesia."

${ }^{32}$ Ejaan yang disepurnakan (EYD) kata Oelama berubah menjadi Ulama, yang kemudian dikenal sebagai Nahdlatul Ulama (NU).

${ }^{33}$ Muzadi, NU Dalam Perspektif Sejarah Dan Ajaran: Refleksi 65 Th. Ikut NU.

${ }^{34}$ Abdurrahman Wahid, Menggerakkan Tradisi ; Esai-Esai Pesantren. Lkis Pelangi Aksara, 2001.

${ }^{35}$ Muzadi, NU Dalam Perspektif Sejarah Dan Ajaran: Refleksi 65 Th. Ikut NU.
} 
kesimpulan bahwa tujuan utama pendirian NU adalah untuk melindungi umat Islam di Indonesia, yang sejak masuknya Islam di Indonesia telah mengadopsi ahlussunnah wal jama'ah dari serangan Wahabi. Berikutnya dinyatakan bahwa NU didirikan dengan tujuan mempertahankan, melestarikan, mengembangkan dan mempraktikkan ajaran Islam dengan mayoritas ahlussunnah wal jama'ah dan berpegang pada salah satu dari empat madzhab; Abu Hanifah, Imam Malik bin Anas, Imam Muhammad bin Idris as Syafi'i dan Imam Ahmad bin Hanbal, untuk menyatukan langkah-langkah ulama dan pengikut mereka dalam melaksanakan kegiatan yang bertujuan menciptakan kemakmuran masyarakat, kemajuan bangsa, martabat manusia yang tinggi dan bermartabat.

\section{NU: Islam Nusantara}

NU mengadakan muktamar pada minggu pertama Agustus 2015. Tema yang diangkat sekilas mirip; NU "Meneguhkan Islam Nusantara untuk Peradaban Indonesia dan Dunia". Tema tersebut adalah jawaban lain untuk fenomena yang ada, yaitu globalisasi, terutama globalisasi budaya, baik dalam bentuk urbanisasi dan westernisasi ${ }^{36}$

Globalisasi sering dipandang sebagai proses menyatukan dunia di mana waktu, jarak, dan ruang tidak lagi menjadi masalah dan ketika segala sesuatu di Bumi saling berhubungan. Ada empat gerakan utama dalam globalisasi: barang, jasa, informasi, individu, dan modal. Pemindahan empat hal dari satu negara ke Negara lain telah terjadi sejak jaman dahulu. Namun, Perpindahan hanya terjadi sangat cepat setelah revolusi dalam teknologi, komunikasi dan transportasi dalam beberapa dekade terakhir. Sebagai hasil dari revolusi, dimensi waktu menjadi tidak jelas dan secara bertahap menghilang. Dalam konteks Indonesia, globalisasi memastikan bahwa orang memiliki akses mudah ke informasi luar atau bekerja sama secara luas dalam ruang global.

Ketika Islamic State of Iraq and Syria (ISIS) mendeklarasikan kekhilafan di bawah Abu Bakar al-Baghdadi, muslim moderat di Indonesia terkejut bahwa sejumlah orang Indonesia telah bergabung dengan mereka di Timur Tengah dan bahwa beberapa anggota merekrut di Indonesia. Ketika konflik Sunni dan Syiah terjadi di Suriah, pengaruh menyebar ke Indonesia dengan munculnya gerakan-gerakan anti-Syiah seperti dalam bentuk Aliansi Nasional Anti-Syiah (ANNAS).

\footnotetext{
${ }^{36}$ Saiful Mustofa, "Meneguhkan Islam Nusantara Untuk Islam Berkemajuan: Melacak Akar Epistemologis Dan Historis Islam (Di) Nusantara," Epistemé: Jurnal Pengembangan Ilmu Keislaman 10, no. 2 (December 6, 2015): 405-434-434, https://doi.org/10.21274/epis.2015.10.2.405-434. 
Pada akhir 2014, sekitar 100 orang Indonesia, mungkin lebih, diyakini telah pergi berperang di Suriah, beberapa dengan istri dan anak-anak mereka, dan sebagian besar bergabung dengan Negara Islam. ${ }^{37}$ ISIS sebagai gerakan lokal di Irak menjadi gerakan transnasional sampai menyebar ke Indonesia. Tujuan ISIS adalah untuk mendirikan kekhalifahan Islam di Irak dan Suriah. Dalam upaya mencapai tujuannya, ISIS menyebarkan ideologinya melalui berbagai propaganda untuk menarik pengikut dari banyak Negara. Dalam konteks Indonesia, afiliasi ISIS terkait erat dengan kelompokkelompok kebangkitan Islam yang telah lama ada di Indonesia. Pemerintah merespons dengan melarang ISIS secara formal dan informal karena ideologi ISIS tidak sesuai dengan Pancasila dan kondisi keragaman di Indonesia. ${ }^{38}$ Gerakan ekstremisme agama dalam perkembangan historisnya sebenarnya bukan murni gerakan jihad atas nama agama, tetapi juga membawa kepentingan politik dan ekonomi sehubungan dengan konspirasi global. ${ }^{39}$

Globalisasi juga menyebabkan Transnasional Capitalist Network (TNC) masuk dalam kehidupan masyarakat dengan mengambil kekayaan yang semestinya dipergunakan untuk kesejahteraan rakyat. Dengan bekerja dengan 'komprador', kapitalis global menciptakan kesenjangan besar antara kaya dan miskin seperti yang terjadi di area pertambangan Freeport di Papua. Filosofi yang mendasari globalisasi adalah asimilasi. Dalam filosofi ini, yang lemah akan mendominasi. Karena itu, dalam globalisasi budaya, salah satu pengaruhnya adalah homogenitas. Contoh lain adalah melihat Islam secara homogen dengan memperkenalkannya ke dalam bahasa Arab dan Arabisasi.

Islam Nusantara adalah istilah yang sering digunakan untuk merujuk ke Islam gaya Indonesia asli; gaya nusantara, tetapi isi dan liriknya Islam; Pakaiannya orang Indonesia, tetapi tubuhnya Islami. Gagasan Islam Nusantara terkait dengan gagasan "Islam asli" yang pernah dipopulerkan oleh almarhum K.H Abdurrahman Wahid..$^{40}$ Bangkitnya Islam Nusantara adalah bagian dari apa yang biasa disebut sebagai "paradoks globalisasi." "Semakin banyak orang mengglobal, semakin sering mereka terobsesi dengan keunikan

${ }^{37}$ Sidney Jones and Solahudin, "ISIS in Indonesia," Southeast Asian Affairs 2015, no. 1 (June 5, 2015): 154-63.

${ }^{38}$ Najamuddin Khairur Rijal, "Eksistensi dan Perkembangan ISIS: Dari Irak Hingga Indonesia," Jurnal Ilmiah Hubungan Internasional 13, no. 1 (August 23, 2017): 45-60, https://doi.org/10.26593/jihi.v13i1.2670.45-60.

${ }^{39}$ M. Zaki Mubarak, "Dari NII Ke ISIS: Transformasi Ideologi Dan Gerakan Dalam Islam Radikal Di Indonesia Kontemporer," Epistemé: Jurnal Pengembangan Ilmu Keislaman 10, no. 1 (June 13, 2015): 77-98-98, https://doi.org/10.21274/epis.2015.10.1.77-98.

${ }^{40}$ Khabibi Muhammad Luthfi, "Islam Nusantara: Relasi Islam Dan Budaya Lokal," Shahih: Journal of Islamicate Multidisciplinary 1, no. 1 (June 28, 2016): 1, https://doi.org/10.22515/shahih.v1i1.53.

Tribakti: Jurnal Pemikiran Keislaman

Volume 31, Nomor 1, Januari 2020 
budaya asli mereka." ${ }^{41}$ Dalam kata-kata ilmuwan lain: "Ketika dunia menjadi lebih perbedaan kecil antara manusia menjadi semakin kecil. " "42

Banyak yang curiga bahwa semakin kita mengenal dunia luar dan berbagai kelompok, semakin terbuka diri kita. Namun, yang sering terjadi tidak sejalan dengan logika itu. Di tengah globalisasi, banyak orang semakin fanatik dan tidak menerima perbedaan dan pluralitas. Ini terjadi, misalnya, dalam sejumlah pemilihan daerah di mana putra pribumi yang dipilih 'diminta'. Dalam konteks global, kita melihat munculnya negara-negara baru dalam keanggotaan Perserikatan Bangsa-Bangsa (PBB) hampir setiap tahun di era globalisasi ini. Tentu saja, respons terhadap globalisasi dalam bentuk "Islam Nusantara" adalah pilihan terbaik dibandingkan dengan penolakan tota atau penerimaan total $^{43}$.

Menanggapi globalisasi, terutama yang dari Barat, beberapa kelompok agama telah mencari perlindungan dalam homogenitas dan eksklusivitas kelompok mereka. Sama seperti perdamaian, itu bisa terjadi dengan menolak keragaman atau sesuatu yang aneh. Di tengah-tengah globalisasi, banyak orang mencoba menutup diri dengan memblokir orang-orang yang berbeda dalam komunitas. Fenomena munculnya rumah atau kluster perumahan eksklusif untuk komunitas keagamaan tertentu, misalnya. Pemakaman/rumah makan dan rumah tamu terkadang adalah penganut agama tertentu. Jawaban untuk globalisasi bahkan lebih buruk, tentu saja dalam bentuk radikalisme dan terorisme. Islam Nusantara dapat menjadi respons yang sangat baik terhadap globalisasi jika tidak mengarah pada parokialisme dan sektarianisme.

\section{Kesimpulan}

Nahdlatul Ulama memiliki sejarah panjang dalam pembetukan moderasi Islam. jika diliah kelahiranya menujukan bahwa NU terlahir atas menguatnya gerakan Wahabi yang radikal dalam melakukan pemusnahan terhadap tradisi dan situs peninggalan para Nabi yang ada di Kawasan Jazirah Arab. Berikutnya menyikapi pergerakan dan perkembangan organisasi Nasional dan keagamaan yang ada di Nusantara. Dua alasan ini menjadikan NU sebagai organisasi penyeimbang di antara kelompok satu dengan yang lainnya.

\footnotetext{
${ }^{41}$ Taufik Bilfagih, "Islam Nusantara; Strategi Kebudayaan Nu Di Tengah Tantangan Global," Aqlam: Journal of Islam and Plurality 1, no. 2 (January 31, 2018), https://doi.org/10.30984/ajip.v1i2.505.

${ }^{42}$ Alexander Raymond Arifianto, "Islam Nusantara: NU's Bid to Promote 'Moderate Indonesian Islam,"” 2016, https://dr.ntu.edu.sg/handle/10220/40704.

${ }^{43}$ Mujamil Qomar, "Islam Nusantara: Sebuah Alternatif Model Pemikiran, Pemahaman, dan Pengamalan Islam," El-Harkah 17, no. 2 (February 5, 2016): 198-217, https://doi.org/10.18860/el.v17i2.3345. 
Pada kontek kekinia, NU masih dalam posisi yang sama sebagai organisasi yang moderat. Di tengah arus globalisasi dengan mengautnya arus informasi dari barat dan Negara-negara Islam lainnya. Maka memposisikan Indonesia sebagai Negara yang mendapatkan dampak globalisasi. Setidaknya globaliasi dari barat membawa purubahan pada sikap liberalisme, yang mendorong seseorang untuk berpikir dan bertindak secara bebas dalam semua aspek kehidupan. Pada sisilain penguatan gerakan Islam trannasional yang cenderung membawa pimikiran dan gerakan radikal. Dalam kondisi ini NU mengabil peran penengah pada arus pemikiran dan pergerakan. Dengan mengambil konsep Islam Nusantara.

\section{Daftar Pustaka}

Althusser, Louis. Tentang Ideologi: Marxisme Strukturalis, Psikoanalisis, Cultural Studies. Yogyakarta: Jalasutra, 2008.

Arifianto, Alexander Raymond. "Islam Nusantara: NU's Bid to Promote 'Moderate Indonesian Islam,"” 2016. https://dr.ntu.edu.sg/handle/10220/40704.

Asyari, Suaidi. Nalar Politik NU-Muhammadiyah; Overcrossing Java Sentris. Yogyakarta: Lkis Pelangi Aksara, 2009.

Benda, Harry J. "Indonesian Islam Under the Japanese Occupation, 1942-45." Pacific Affairs 28, no. 4 (1955): 350-62. https://doi.org/10.2307/3035318.

Bilfagih, Taufik. "Islam Nusantara; Strategi Kebudayaan Nu Di Tengah Tantangan Global." Aqlam: Journal of Islam and Plurality 1, no. 2 (January 31, 2018). https://doi.org/10.30984/ajip.v1i2.505.

Bruinessen, Martin van. Kitab kuning, pesantren, dan tarekat: tradisi-tradisi Islam di Indonesia. Bandung: Mizan, 1999.

—. NU: Tradisi, Relasi-Relasi Kuasa, Pencarian Wacana Baru. Yogyakarta: Lkis Pelangi Aksara, 1994.

Bush, Robin, and Greg Fealy. "The Political Decline of Traditional Ulama in Indonesia." Asian Journal of Social Science 42 (January 1, 2014): 536-60. https://doi.org/10.1163/15685314-04205004.

Chalik, Abdul. "Terjebak Antara Demokrasi Dan Kedaulatan Negara: Anomali Pembubaran Hizbut Tahrir Indonesia Dan Bayang- Bayang NeoOtoritarianisme," 51-68. Surabaya - $\quad$ Indonesia, 2017. http://digilib.uinsby.ac.id/id/eprint/23566.

Dahrendorf, Ralf. Konflik Dan Konflik Dalam Kelas Masyarakat Industri; Sebuah Analisa Kritik. Jakarta: Rajawali, 1986.

Darajat, Zakiya. "Muhammadiyah Dan NU: Penjaga Moderatisme Islam Di Indonesia." Hayula: Indonesian Journal of Multidisciplinary Islamic Studies 1, no. 1 (January 30, 2017): 79-94. https://doi.org/10.21009/hayula.001.1.05. 
Dhofier, Zamakhsyari. The Pesantren Tradition: The Role of the Kyai in the Maintenance of Traditional Islam in Java. Arizona: Monograph Series Press, Program for Southeast Asian Studies, Arizona State University, 1999.

Fealy, Greg. Ijtihad Politik Ulama ; Sejarah NU 1952-1967. Lkis Pelangi Aksara, 2012. "Ulama and Politics in Indonesia: A History of Nahdlatul Ulama, 1952-1967." Disertasi, Monash University, 1998.

Fealy, Greg, and Robin Bush. "The Political Decline of Traditional Ulama in Indonesia The State, Umma and Nahdlatul Ulama." Asian Journal of Social Science 42, no. 5 (2014): 536-60.

Feilliard, Andree. NU Vis-a-Vis- Negara. Yogyakarta: LKiS, 1999.

Fuad, A. Jauhar. "Infiltrasi Salafi Wahabi pada Buku Teks di Madrasah dan Respons Warga Nahdliyin.” Marâjiı: Jurnal Ilmu Keislaman 1, no. 2 (March 2, 2015): 361-92.

Fuad, A. Jauhar, and Suko Susilo. "Mainstreaming Of Islamic Moderation In Higher Education: The Radical Experience Conter." Proceedings of Annual Conference for Muslim Scholars 3, no. 1 (November 26, 2019). http://proceedings.kopertais4.or.id/index.php/ancoms/article/view/261.

Geertz, Clifford. The Religion of Java. London: University of Chicago Press, 1976.

Hilmy, Masdar. "Whither Indonesia's Islamic Moderatism? A Reexamination on the Moderate Vision of Muhammadiyah and NU." Journal of Indonesian Islam 7, no. 1 (June 1, 2013): 24-48. https://doi.org/10.15642/JIIS.2013.7.1.24-48.

Jasminto, Jasminto. "Urgensi Teori Andragogi Dalam Memperkuat Visi Moderat Islam Di Indonesia." In Proceedings: Annual Conference for Muslim Scholars, 643-51, 2018. http://proceedings.kopertais4.or.id/index.php/ancoms/article/view/166.

Jones, Sidney, and Solahudin. "ISIS in Indonesia." Southeast Asian Affairs 2015, no. 1 (June 5, 2015): 154-63.

Kahin, George McTurnan. Nationalism and Revolution in Indonesia. SEAP Publications, 2003.

Keddie, Nikki R., and Jamāl al-Dīn Afghānī. An Islamic Response to Imperialism: Political and Religious Writings of Sayyid Jamal Ad-Din "al-Afghani." University of California Press, 1983.

Liputan6.com. "Ada Bendera HTI di SMKN 2 Sragen, GP Ansor: Pelajar Harusnya Steril dari Radikalisme." liputan6.com, October 17, 2019. https://www.liputan6.com/regional/read/4088206/ada-bendera-hti-di-smkn-2sragen-gp-ansor-pelajar-harusnya-steril-dari-radikalisme.

Luthfi, Khabibi Muhammad. "Islam Nusantara: Relasi Islam Dan Budaya Lokal." Shahih: Journal of Islamicate Multidisciplinary 1, no. 1 (June 28, 2016): 1. https://doi.org/10.22515/shahih.v1i1.53.

Mobini-Kesheh, Natalie. The Hadrami Awakening: Community and Identity in the Netherlands East Indies, 1900-1942. Cornell: SEAP Publications, 1999. 
Mubarak, M. Zaki. "Dari NII Ke ISIS: Transformasi Ideologi Dan Gerakan Dalam Islam Radikal Di Indonesia Kontemporer." Epistemé: Jurnal Pengembangan Ilmu Keislaman 10, no. 1 (June 13, 2015): 77-98-98. https://doi.org/10.21274/epis.2015.10.1.77-98.

Mustofa, Saiful. "Meneguhkan Islam Nusantara Untuk Islam Berkemajuan: Melacak Akar Epistemologis Dan Historis Islam (Di) Nusantara." Epistemé: Jurnal Pengembangan Ilmu Keislaman 10, no. 2 (December 6, 2015): 405-434-434. https://doi.org/10.21274/epis.2015.10.2.405-434.

Muzadi, Abdul Muchith. NU Dalam Perspektif Sejarah Dan Ajaran: Refleksi 65 Th. Ikut NU. Surabaya: Khalista, 2006.

Nashrullah, Nashih. "BNPT: TNI Dan Polri Bisa Terpapar Radikalisme Terorisme." Republika Online, September 24, 2019. https://republika.co.id/share/pybqpt320.

Qohar, Abd, and Kiki Muhamad Hakiki. "Eksistensi Gerakan Idiologi Transnasional HTI Sebelum dan Pasca Pembubaran." KALAM 11, no. 2 (December 31, 2017): 36596. https://doi.org/10.24042/klm.v11i2.1403.

Qomar, Mujamil. "Islam Nusantara: Sebuah Alternatif Model Pemikiran, Pemahaman, dan Pengamalan Islam." El-Harkah 17, no. 2 (February 5, 2016): 198-217. https://doi.org/10.18860/el.v17i2.3345.

Rijal, Najamuddin Khairur. "Eksistensi dan Perkembangan ISIS: Dari Irak Hingga Indonesia." Jurnal Ilmiah Hubungan Internasional 13, no. 1 (August 23, 2017): 45-60. https://doi.org/10.26593/jihi.v13i1.2670.45-60.

Ryacudu, Ryamizard. "Menhan Sebut 3 Persen Anggota TNI Terpapar Radikalisme." nasional, 2019. https://www.cnnindonesia.com/nasional/20190619113157-20404549/menhan-sebut-3-persen-anggota-tni-terpapar-radikalisme.

Steenbrink, Karel A. Dutch Colonialism and Indonesian Islam: Contacts and Conflicts, 1596-1950. Amsterdam-New York: Rodopi, 2006.

Sugiharto, Jobpie. "Penusukan Wiranto, Pengamat: Jadi Sorotan Internasional." Tempo, October 11, 2019. https://nasional.tempo.co/read/1258498/penusukan-wirantopengamat-jadi-sorotan-internasional.

Sulistya, Prima. "Ribetnya Jadi Orang Islam yang Dinamai Pakai Nama Sanskerta Menyerupai Dewa-Dewi Hindu - Mojok.co.” Mojok (blog), October 7, 2019. https://mojok.co/prm/ulasan/pojokan/ribetnya-jadi-orang-islam-yang-dinamaipakai-nama-sanskerta-menyerupai-dewa-dewi-hindu/.

Syamlan, Syamlan. "Kebijakan Pemerintah Indonesia Terhadap Pembubaran Organisasi Hizbut Tahrir Indonesia (HTI)." Thesis, MIHI UMY, 2018. http://repository.umy.ac.id/handle/123456789/21498.

Tim detikcom. "Polwan Terpapar Radikalisme Dipecat Dari Institusi Polri." detiknews, 2019. https://news.detik.com/berita/d-4743324/polwan-terpapar-radikalismedipecat-dari-institusi-polri.

Wahid, Abdurrahman. Menggerakkan Tradisi; Esai-Esai Pesantren. Lkis Pelangi Aksara, 2001. 
Yusqi, Ishom. "Kemenag Jadikan Moderasi Islam Sebagai Arus Utama Pendidikan Islam." Kementrian Agama Republik Indoneisa, March 18, 2017. https://www2.kemenag.go.id/berita/472922/kemenag-jadikan-moderasi-islamsebagai-arus-utama-pendidikan-islam. 